\title{
Working
}

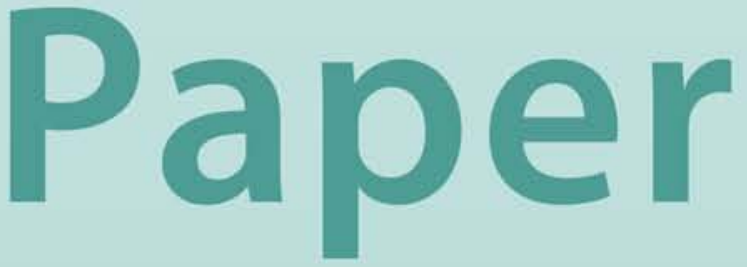




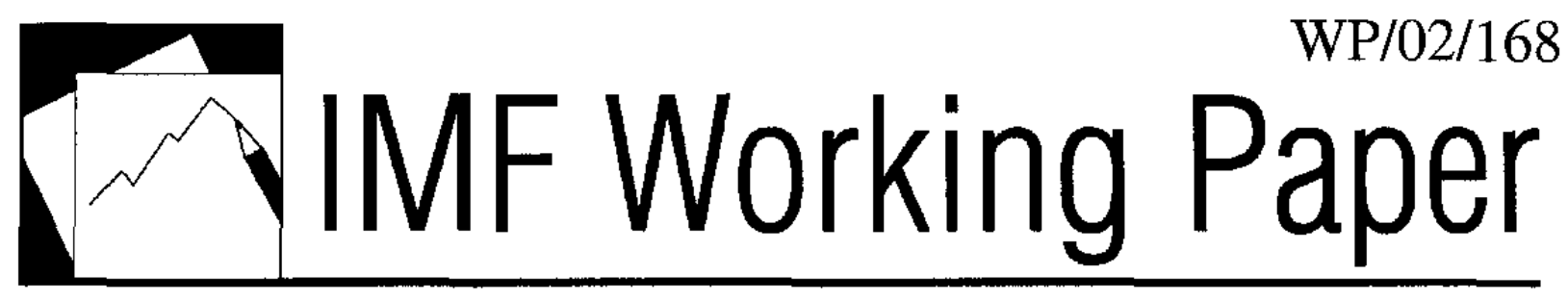

Recentralization in China?

Ehtisham Ahmad, Li Keping, Thomas Richardson, and Raju Singh 


\title{
IMF Working Paper
}

\author{
Fiscal Affairs Department
}

\section{Recentralization in China?}

\author{
Prepared by Ehtisham Ahmad, Li Keping, Thomas Richardson, and Raju Singh ${ }^{1}$
}

October 2002

\begin{abstract}
The views expressed in this Working Paper are those of the author(s) and do not necessarily tepresent those of the IMF or IMF policy. Working Papers describe research in progress by the author(s) and are published to elicit comments and to further debate.
\end{abstract}

The paper assesses the changing nature of the relations between the provinces and the central government in China during the 1990s. It examines the fiscal reforms initiated in 1994 and subsequent developments. The expenditure needs of the center and the richer provinces are juxtaposed against the need for "redistribution" to the more backward regions.

JEL Classification Numbers: H7

Keywords: Intergovernmental Relations

Authors’ E-Mail Addresses: eahmad@imf.org; trichardson@imf.org; rsingh2@imf.org; lkp@ht.rol.cn.net

\footnotetext{
${ }^{1}$ This paper was presented al a Conference on "Fiscal Decentralization" held at the IMF in November 2000 and is to be published in Ehtisham Ahmad and Vito Tanzi, eds., Managing Fiscal Decentralization (London and New York: Routledge). At the time of writing, Ahmad, Richardson, and Singh were with the Fiscal Affairs Department of the IMF, and Li Keping was with the Systems Reform Commission, State Council, People's Republic China. Helpful comments from Wei Benhua, Christine Wallich, and Harm Zebregs are acknowledged.
} 


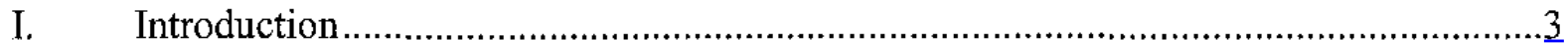

II. Conflicting Trends in China's Fiscal Decentralization.............................................

A. Pre-1994: Fiscal Decentralization ..............................................................4

B. 1994 Reform and After: Recentralization ......................................................... 6

III. Macroeconomic Management with Multilevel Administration in China-

The Recent Past ...................................................................................

A. Decentralization and Growth …………......................................................16

B. Decentralization and Fiscal Risk....................................................................

IV. Implications of Changing Intergovernmental Dynamics.......................................20

A. Revenue Assignments - Vertical and Horizontal Imbalances? ............................20

B. Specification of Expenditure Assignments ………….........................................21

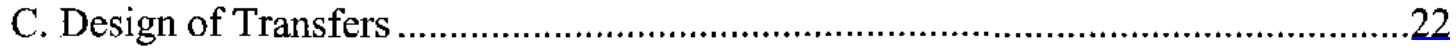

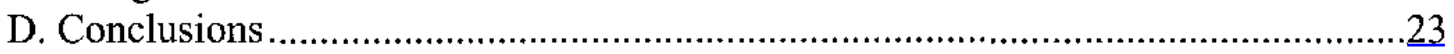

Tables

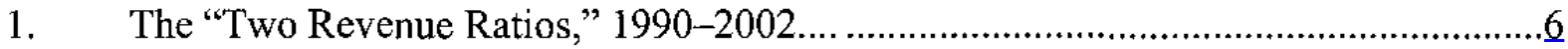

2. China: State Budget, Central and Local Components ..............................................

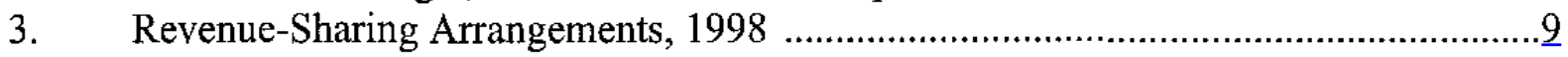

Figures

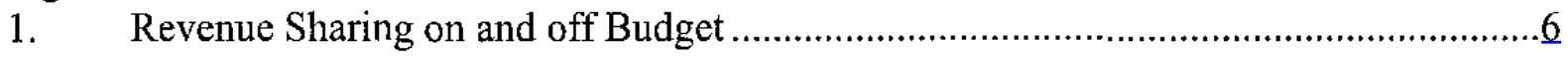

2. Extrabudgetary Share of Total Revenue ...........................................................

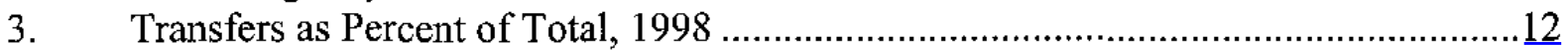

4. Total Transfers Per Capita and GDP, Per Capita in 1998.......................................13

5. Total Transfers and Own Revenue, as Percent of GDP, in 1998.............................13

6. Per Capita Revenue Returned and Per Capita GDP in 1998 ...................................14

7. Per Capita Transfers Other than Revenue Returned and Per Capita GDP in 1998 ......14

8. Composition of Revenue in Four Provinces, 1998 .................................................22

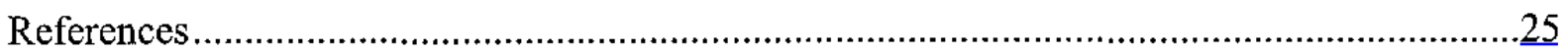




\section{INTRODUCTION}

China is a unitary state with five levels of administration. There are 31 provincial-level units (22 provinces, 4 large cities directly under the central government, and 5 autonomous regions), which average over 40 million in population. Below these provinces are 335 prefectures and cities at the prefectural level; 2,142 counties, autonomous counties and cities at the county level; and a large number of townships, towns, and city districts. ${ }^{2}$ Prior to the reforms of 1994, there was a single tax administration responsible for all taxes, which, given the numbers of staff involved, remained largely under the control of provincial governments.

The focus in this paper is on central-provincial relations, though similar issues exist at lower levels as well and most Chinese provinces are larger in size or population than many independent countries around the world.

China's intergovernmental fiscal system has evolved over twenty years of economic restructuring, albeit with a major reform in 1994. A number of the steps taken by the authorities over the course of this period have been aimed at redressing one or another type of dysfunctional behavior. The effective fiscal decentralization of the $1980 \mathrm{~s}$ and early $1990 \mathrm{~s}$ was marked by rapid growth together with increasing regional inequalities and declining general government revenues, a phenomenon also associated with the restructuring of the previously centrally planned economy.

The radical 1994 tax reform — which clearly delineated central, local, and shared taxes, and established central administration (for the major taxes) - was an attempt to establish a uniform tax system. The central government's share of revenues (before transfers) increased from around 35 percent of general revenues to just under 60 percent. However, in order to satisfy the coastal provinces that generate much of the revenues, a lump-sum transfer to guarantee them their pre-1994 income levels was agreed. A new equalization transfer scheme was expected to be introduced to gradually replace the lumpsum transfers.

In any event, the equalization transfer mechanism has remained small-and additional revenue returns have been negotiated with the coastal provinces, thus virtually preserving the pre-1994 pattern of interregional local revenues. ${ }^{3}$ The regional income imbalances remain, particularly vis-à-vis the western and interior provinces, relative to the coastal regions.

Addressing the regional imbalances, as well as expenditures relating to the reform of the state-owned enterprise (SOE) and financial sectors and restructuring of the social-protection

\footnotetext{
${ }^{2} \mathrm{Ma}$ and Norregaard (1998). These figures exclude Hong Kong SAR, Macao SAR, and Taiwan POC.

${ }^{3}$ The term "local" in China is taken to mean all subnational levels of government, including provinces and municipalities, counties and townships.
} 
system, will require additional central resources. This paper addresses the pressures for a new intergovernmental arrangement in China.

The structure of the present paper is as follows. A brief overview of the Chinese fiscal system is presented in the Section II. This summary of the current state of affairs is followed by a discussion of the challenges of SOE and financial sector reform in Section III. Section IV is concerned with possible reforms to the revenue sharing, expenditure assignment and transfer systems, respectively.

\section{Conflicting Trends in China’s Fiscal Decentralization}

\section{A. Pre-1994: Fiscal Decentralization}

A fiscal revenue sharing system was established in 1980 with the objective of providing subnational governments with an incentive to collect revenue. Under that system, centralprovincial sharing rules were established by the central government, provincial-municipal relations were governed by the province, and this principle extended to lower levels. For the most part, enterprises, which were subordinate to the central government, were supposed to pay taxes to the center; and those, which were subordinate to lower level governments, paid at that level. Indeed, in this early reform period, both local governments and SOEs had relatively similar roles as agents of the central government. Revenue, or income in excess of expenses, was to be transferred to the central government and shortfalls were to be covered automatically. In practice, the incentives for the local government were to reduce the revenue transfer to the center, and heighten the need for transfers from the center. Local enterprises and local governments had reason to collude to hide revenue from the center. The revenuesharing system during the period 1980-88 was associated with a significant reduction in revenue collections as a share of GDP.

Some analysts have argued that this system gave local governments an incentive to develop industries, which would earn a healthy profit. ${ }^{4}$ But it also gave rise to protectionist barriers to interregional trade.

Note that, while the intergovernmental fiscal system in the early 1980 s afforded local governments relatively little incentive to collect revenue, tax administration factors also contributed to the revenue decline. As the role of market forces in the economy grew, rapidly changing prices and quantities made it harder for tax collectors to monitor enterprise behavior. Further, the number of taxpayers increased dramatically. For example, the agricultural tax was at one point collected from 50,000 communes, but after the reforms the

\footnotetext{
${ }^{4}$ Qian (1999).
} 
number of taxpayers rose to more than 200 million households and TVEs. As a result, the authorities introduced four different revenue sharing arrangements during the $1980 \mathrm{~s}^{5}$

Finally, in 1988 a "fiscal contracting" system was implemented under which provincial governments each negotiated a fixed tax quota with the center, with collections above that

level being retained at the local level. (This approach, dubbed "eating in separate kitchens," was also introduced at lower levels of government.)

The new system also created a strong incentive for local governments to conceal information about local revenue from the center, else they would face a "ratchet effect," as this information would be valuable at the time the fiscal contracts were renegotiated.

Furthermore, many of the new enterprises in the rapidly expanding township and village enterprise sector were joint ventures with local government ownership. With retained profits accruing to the benefit of "local shareholders," there was a continued incentive to shift deficits to the center and hide profits from taxation. Thus, the system heightened an asymmetry, in that local governments absorbed excess revenues, while deficits were covered by the center. ${ }^{6}$

In addition, on several occasions during the 1980s the central government "borrowed" revenue from local governments, and also introduced new taxes meant to absorb local revenue that the central government felt was excessive. As a result, although they did not formally control statutory tax rates, local governments did so effectively through selective use of tax incentives, while significant revenues were diverted off budget into myriad extrabudgetary funds that were financed by fees, charges and other levies ${ }^{7}$ (see Figure 1).

Thus, at the same time as the growth of the non-state sector was causing problems for tax administration (overall state budget revenue as a share of GDP fell from $251 / 2$ percent in 1985 to 13.7 percent in 1993), the sharing rules were causing a shift of resources from the center to the provinces (see Table 1). The central government's share of revenue fell from 38.5 percent in 1985 to 28 percent in 1992 (and to 22 percent in $1993^{8}$ ). As a consequence, during the early 1990s the authorities considered the central government's share of total revenues (just 2 percent of GDP during 1991-93) to be seriously inadequate, and a radical reform of the fiscal system was initiated.

\footnotetext{
${ }^{5}$ Wong $(1997,2000)$.

${ }^{6}$ Ahmad (1997), Laffont (1999), Ma (1997), Wong (1991, 1995).

${ }^{7} \mathrm{Ma}$ and Norrcgaard (1998).

${ }^{8}$ The central government announced in August 1993 that 1993 would be the base year for the new fiscal federal arrangement introduccd in 1994. As a result, local government revenues ballooned during the last four months of the year. See Wong (2000).
} 


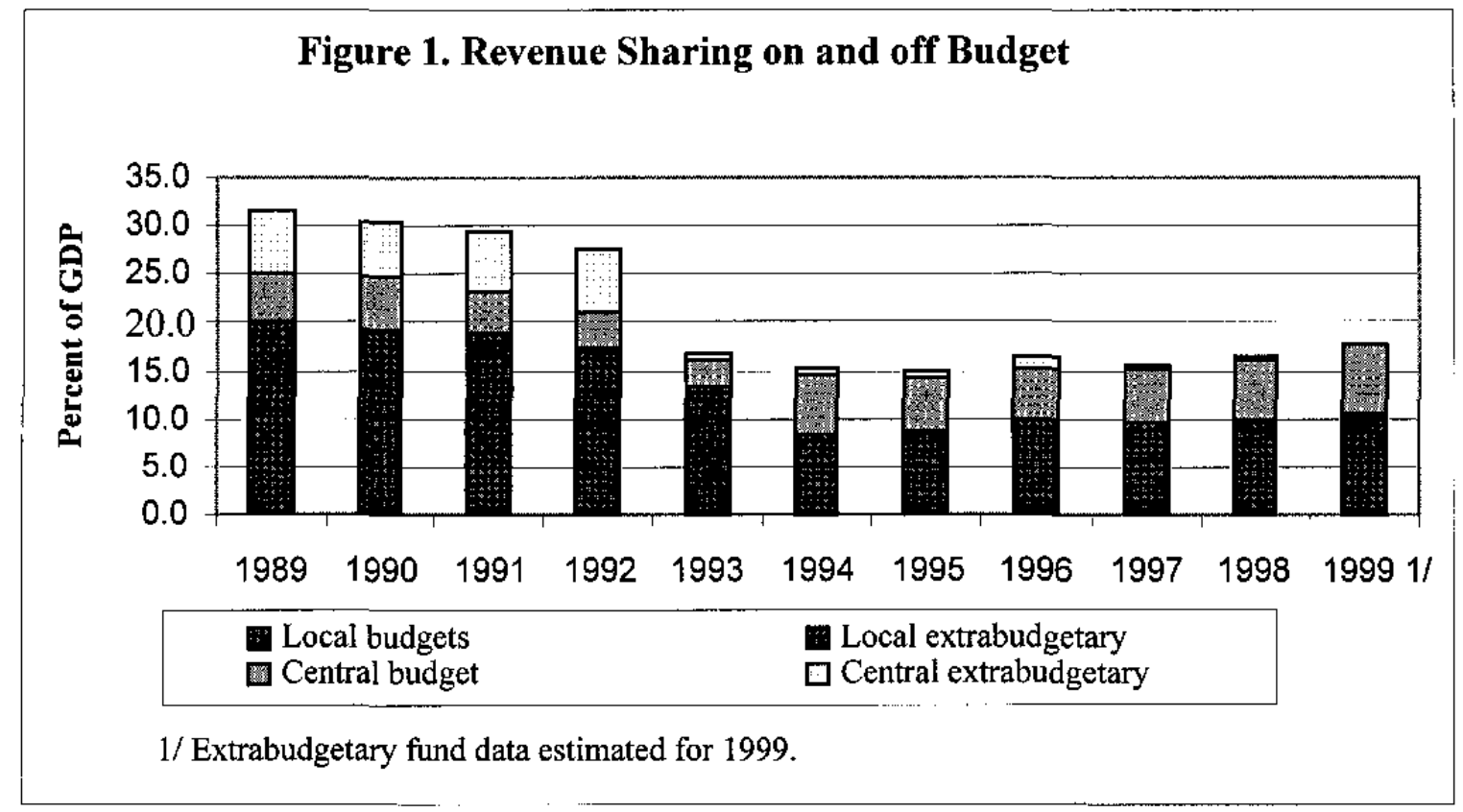

Table 1. The "Two Revenue Ratios," 1990-2002

\begin{tabular}{lccccccccccccc}
\hline & 1990 & 1991 & 1992 & 1993 & 1994 & 1995 & 1996 & 1997 & 1998 & 1999 & 2000 & 2001 & 2002 \\
\hline $\begin{array}{l}\text { Revenue share } \\
\text { in GDP 1/ }\end{array}$ & 19.1 & 17.0 & 14.7 & 13.7 & 11.9 & 11.1 & 11.2 & 12.1 & 13.0 & 14.3 & 15.3 & 17.2 & 17.8 \\
\hline $\begin{array}{l}\text { Central share } \\
\text { in revenue } \\
\text { (MoF }\end{array}$ & 33.8 & 29.8 & 28.1 & 22.0 & 55.7 & 52.2 & 49.4 & 48.9 & 49.5 & 51.1 & 52.2 & 52.4 & 55.8 \\
$\begin{array}{l}\text { definition) } \\
\begin{array}{l}\text { Central share } \\
\text { in revenue } \\
\text { (IMF } \\
\text { definition) }\end{array}\end{array}$ & $\ldots$ & $\ldots$ & $\ldots$ & $\ldots$ & $\ldots$ & 50.8 & 48.3 & 47.9 & 48.8 & 49.9 & 51.2 & 51.5 & 54.9 \\
\hline
\end{tabular}

Source: Ministry of Finance and IMF staff calculations.

Note: Budgeted figures for 2002.

1/ Unless otherwise specified, revenue, expenditure and deficit figures for the state budget are on IMF definitions, which for revenue differ from official definitions in that losses of SOEs are reclassified from negative revenue to expenditure.

\section{B. 1994 Reform and After: Recentralization}

The authorities had four main goals for the 1994 fiscal reform, though only some of these have been achieved in practice (see Wong, 2000). These were to:

- Simplify the tax system. 
- $\quad$ Raise the revenue to GDP ratio.

- $\quad$ Raise the ratio of central government to total revenue.

- $\quad$ Make the fiscal federal system more stable by shifting from ad hoc, negotiated transfers to a rule-based tax assignment.

Progress was most pronounced with respect to the first objective, while for the other three the results of the 1994 reform have proven to be somewhat disappointing. These four objectives are discussed more fully in the sections below.

\section{Revenue trends}

Although the system continues to embody a number of serious distortions, under the 1994 reform, the tax structure was indeed simplified. A new value-added tax (VAT) replaced the turnover based product tax; excise taxes (called consumption taxes) on tobacco, liquor and other luxuries were introduced; and the treatment of enterprises under the corporate income tax was largely unified, with the top rate reduced. ${ }^{9}$ SOE profit and tax contracts, whereby firms negotiated annual transfers to the budget, were largely eliminated in favor of the uniform tax code.

The 1994 reform also involved a significant modification of revenue sharing rules, along with a substantial increase in the importance of fiscal transfers. Under the reformed fiscal system, tax revenue assigned to the central government included the following: 75 percent of the newly introduced VAT, excises, trade related taxes (customs duties, excises and the VAT levied on imports), the enterprise income tax collected from central SOEs, turnover taxes on the railroads and financial sector, and most of a securities stamp tax (see Table 2). At the same time, a national tax service was established to administer the new central and shared revenue system. This has involved an enormous and ongoing effort on the part of the center to administer the main revenue sources in China.

Local governments were assigned the following revenue sources: $1 / 4$ of the VAT, the business tax (apart from that collected from banks, railroads and insurance companies), enterprise income taxes levied on local SOEs, the personal income tax, and a number of smaller taxes.

As seen in Table 3, the main goal of this reform was to increase the "two ratios"-revenue to GDP and central revenue as a share of the total. Given the context of a declining state budget revenue to GDP ratio, which fell by 4 percent of GDP between 1991-95, local government revenues-including transfers - fell as well, from 11/1/2 to 91/4 percent of GDP. In 1996, it

\footnotetext{
${ }^{9}$ See Bahl (1999), Chapter 3, for a good summary.
} 
Table 2. China: State Budget, Central and Local Components (Official Definitions)

(In percent of GDP)

\begin{tabular}{|c|c|c|c|c|c|c|c|c|c|c|c|c|c|}
\hline & $\begin{array}{r}19801 / \\
\text { Actual } \\
\end{array}$ & $\begin{array}{r}19851 / \\
\text { Actual } \\
\end{array}$ & $\begin{array}{r}1990 \\
\text { Actual } \\
\end{array}$ & $\begin{array}{r}1991 \\
\text { Actual }\end{array}$ & $\begin{array}{r}1992 \\
\text { Actual }\end{array}$ & $\begin{array}{r}1993 \\
\text { Actual }\end{array}$ & $\begin{array}{r}1994 \\
\text { Actual } \\
\end{array}$ & $\begin{array}{r}1995 \\
\text { Actual } \\
\end{array}$ & $\begin{array}{r}1996 \\
\text { Actual } \\
\end{array}$ & $\begin{array}{r}1997 \\
\text { Actual } \\
\end{array}$ & $\begin{array}{c}1998 \\
\text { Actual } \\
\end{array}$ & $\begin{array}{c}1999 \\
\text { Actual }\end{array}$ & $\begin{array}{c}2000 \\
\text { Budget }\end{array}$ \\
\hline Total revenue & 25.7 & 22.4 & 15.8 & 14.6 & 13.1 & 12.6 & 11.2 & 10.6 & 10.7 & 11.6 & 12.4 & 13.9 & 13.9 \\
\hline Total expenditure & 27.2 & 22.4 & 16.6 & 15.7 & 14.0 & 13.4 & 12.4 & 11.6 & 11.5 & 12.4 & 13.6 & 16.0 & 16.5 \\
\hline Balance & -1.5 & 0.0 & -0.8 & -1.1 & -1.0 & -0.8 & -1.2 & -1.1 & -0.8 & -0.7 & -1.2 & -2.1 & -2.6 \\
\hline Central revenue & 6.3 & 8.6 & 8.0 & 6.6 & 5.8 & 4.5 & 7.4 & 6.6 & 6.2 & 6.5 & 6.9 & 7.8 & 7.8 \\
\hline Own reveriue & 6.3 & 8.6 & 5.4 & 4.3 & 3.7 & 2.8 & 6.2 & 5.5 & 5.3 & 5.7 & 6.2 & 7.1 & 7.1 \\
\hline Transfers from local levels & $\ldots$ & $\ldots$ & 2.6 & 2.3 & 2.1 & 1.7 & 1.2 & 1.0 & 0.9 & 0.8 & 0.8 & 0.7 & 0.7 \\
\hline Central expenditure & 14.8 & 8.9 & 8.6 & 7.6 & 6.6 & 5.4 & 8.9 & 7.7 & 7.1 & 7.2 & 8.1 & 10.0 & 10.4 \\
\hline Own expenditure & 14.8 & 8.9 & 5.4 & 5.0 & 4.4 & 3.8 & 3.8 & 3.5 & 3.1 & 3.4 & 4.0 & 5.0 & 5.4 \\
\hline Transfers to local levels & $\ldots$ & $\ldots$ & 3.2 & 2.6 & 2.2 & 1.6 & 5.1 & 4.2 & 4.0 & 3.8 & 4.2 & 5.0 & 5.0 \\
\hline Central government balance & -8.5 & -0.3 & -0.6 & -1.0 & -0.9 & -0.9 & -1.4 & -1.1 & -0.9 & -0.8 & -1.2 & -2.2 & -2.6 \\
\hline Local revenue & 19.4 & 13.8 & 13.6 & 12.8 & 11.6 & 11.4 & 10.1 & 9.3 & 9.4 & 9.8 & 10.4 & 11.8 & 11.8 \\
\hline Own revenue & 19.4 & 13.8 & 10.5 & 10.2 & 9.4 & 9.8 & 4.9 & 5.0 & 5.4 & 5.9 & 6.3 & 6.8 & 6.8 \\
\hline Transfers from central government & $\ldots$ & $\ldots$ & 3.2 & 2.6 & 2.2 & 1.6 & 5.1 & 4.2 & 4.0 & 3.8 & 4.2 & 5.0 & 5.0 \\
\hline Local expenditure & 12.4 & 13.5 & 13.8 & 12.9 & 11.8 & 11.3 & 9.9 & 9.2 & 9.3 & 9.8 & 10.4 & 11.7 & 11.8 \\
\hline Own expenditure & 12.4 & 13.5 & 11.2 & 10.6 & 9.7 & 9.6 & 8.6 & 8.2 & 8.4 & 9.0 & 9.6 & 11.0 & 11.1 \\
\hline Transfers to central government & $\ldots$ & $\ldots$ & 2.6 & 2.3 & 2.1 & 1.7 & 1.2 & 1.0 & 0.9 & 0.8 & 0.8 & 0.7 & 0.7 \\
\hline Local government balance & 6.9 & 0.3 & -0.2 & -0.1 & -0.1 & 0.0 & 0.2 & 0.1 & 0.1 & 0.0 & 0.1 & 0.0 & 0.0 \\
\hline \multicolumn{14}{|l|}{ Memorandum items: } \\
\hline GDP (RMB Billion) & 451.8 & 896.4 & $1,854.8$ & $2,161.8$ & $2,663.8$ & $3,463.4$ & $4,675.9$ & $5,847.8$ & $6,859.4$ & $7,446.3$ & $7,939.6$ & $8,205.4$ & $8,864.9$ \\
\hline Ratio of central revenue to total revenue & 24.5 & 38.4 & 33.8 & 29.8 & 28.1 & 22.0 & 55.7 & 52.4 & 49.5 & 48.8 & 49.7 & 51.0 & 51.1 \\
\hline
\end{tabular}

Source: Ministry of Finance, New China Fifty Years' Government Finance Statistics, (2000).

1/ Data on intergovernmental transfers unavailable before 1990. 
Table 3. Revenue-Sharing Arrangements, 1998

\begin{tabular}{|c|c|c|}
\hline Level & $\operatorname{Tax}$ & $\begin{array}{l}\text { Central Share } \\
\text { (In percent) }\end{array}$ \\
\hline \multirow[t]{3}{*}{ Central taxes } & Domestic excises & 100 \\
\hline & Customs duties & 100 \\
\hline & VAT and excises on imports & 100 \\
\hline \multirow[t]{13}{*}{ Local taxes } & Personal income tax & 0 \\
\hline & City and township land use tax & 0 \\
\hline & Farmland occupation tax & 0 \\
\hline & Fixed assets investment orientation tax & 0 \\
\hline & Land appreciation tax & 0 \\
\hline & House property tax & 0 \\
\hline & Urban real estate tax & 0 \\
\hline & Vehicle and vessel use tax & 0 \\
\hline & Vehicle and vessel license plate tax & 0 \\
\hline & Deed tax & 0 \\
\hline & Slaughter tax & 0 \\
\hline & Banquet tax & 0 \\
\hline & Agricultural and animal husbandry taxes & 0 \\
\hline \multirow[t]{13}{*}{ Shared taxes } & Domestic VAT & 75 \\
\hline & $\begin{array}{l}\text { Business tax - if paid by railroads, headquarters of banks or insurance } \\
\text { companies, and } 3 \% \text { resource tax }\end{array}$ & 100 \\
\hline & Business tax-otherwise & 0 \\
\hline & $\begin{array}{l}\text { Enterprise income tax-if paid by railroads, headquarters of financial } \\
\text { institutions and insurance companies belonging to the central } \\
\text { government }\end{array}$ & 100 \\
\hline & Enterprise income tax-otherwise & 0 \\
\hline & Income tax on foreign and foreign funded banks & 100 \\
\hline & Income tax on foreign and foreign funded nonbanks & 0 \\
\hline & Resource tax-if paid by offshore oil companies & 100 \\
\hline & Resource tax-otherwise & 0 \\
\hline & $\begin{array}{l}\text { City maintenance and construction tax-if paid by railroads, } \\
\text { headquarters of banks or insurance companies }\end{array}$ & 100 \\
\hline & City maintenance and construction tax-otherwise & 0 \\
\hline & Securities tax-if collected on stock transactions & 88 \\
\hline & Securities tax - otherwise & 0 \\
\hline
\end{tabular}

Sourcc: SAT, Tax System of the People's Republic of China (1998), p. 60. 
began to rise slowly, and has risen more rapidly in 1998-99 as a result of improved tax administration, especially the anti-smuggling effort, combined with more effective treasury controls.

After the one-off increase in the central government revenue ratio in 1994, local governments recouped some of their share, as local revenues grew more rapidly than that of the center during 1995-97. More recently the anti-smuggling campaign in 1998-99 had some effect on the central government's share in total revenues, since all customs related taxes (duties, VAT and excises) accrue to the center. But the authorities' objective of raising the central share to 60 percent has in general not been achieved.

At the same time, central government transfers to the provinces nearly tripled, rising from $11 / 2$ percent of GDP in 1993 to more than 4 percent in 1995. However, although one of the "two ratios" was rising, overall state budget revenues continued to deteriorate, falling by 4 percent of GDP between 1991-95. Thus, local government revenues (including transfers) fell as well, from $11 \frac{1 / 2}{2}$ to $9 \frac{1}{4}$ percent of GDP, though these figures have rebounded in recent years.

Local governments continue to have very limited tax setting ability under the 1994 reform, at least in a formal sense. They can only modify the rates of a few minor taxes, and all other revenue decisions need to be taken by Beijing. This factor has given rise to continued incentives for local governments to raise revenue outside the budget system, in the form of fees and charges which accrue to locally managed extrabudgetary funds, over which the local officials have complete control and face virtually no oversight. These extrabudgetary funds continue to generate a significant portion of total revenue at the local level. After 1994, changes in budget recording make it difficult to assess the central government's use of this mechanism (see Figure 2). Although the recorded share of central government revenues collected off budget fell from an average of 50.4 percent during 1989-93 to 7.9 percent during 1994-99, this was in part due to the exclusion from the extrabudgetary accounts of SOE profits after 1993. Nevertheless, the ratio of local off-budget revenues to total local revenues remained in the neighborhood of 40 percent throughout ( 42.0 percent during the former period and 39.3 percent during the latter).

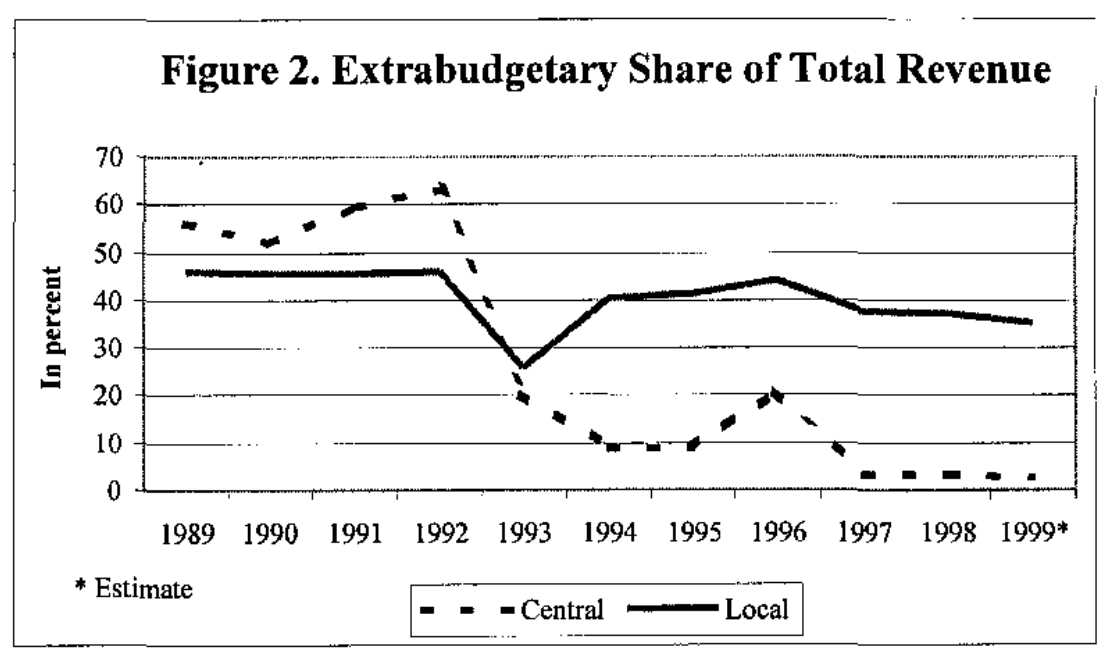


In addition to the use of extrabudgetary funds, local governments also have levers by which they can influence the behavior of State Administration of Taxation (SAT) officials based in their jurisdictions. These measures include the access to services such as water, power, housing and schools. Some local authorities have reportedly used such levers to ensure that local revenues are collected before revenues accruing to the center, leading in some cases to the under-collection of central government revenue. ${ }^{10}$

An issue of concern to the central government in the recent past has been the proliferation of fees and charges instituted by various local governments, causing considerable hardship and nuisance for the population in various localities. Such "unauthorized" use of revenue handles has the potential to cause social unrest and political difficulties for the center.

Attempts by the center to replace user fees and charges by a fuel tax were seen as an intrusion by the local governments, and the attempt to "recentralize" was strongly resisted. However, as seen below, there can be an effective sharing of the base of the fuel tax between different levels of government, allowing each to set rates (within bounds) to meet their respective expenditure needs.

Further, the incentive to hide revenue by local authorities exacerbates pressures on the central government's finances in that it has at its disposal a relatively small share of overall fiscal resources to finance a variety of expenditures that are difficult to adjust (such national defense) and others such as social security and interest on government debt that are likely to increase over time.

\section{Transfer mechanisms}

In theory, the 1994 transfer mechanism was a major improvement over the older ad hoc system based on annual negotiations. In the event, the political bargain struck to secure the tax-sharing reforms has served to undermine the equalization objectives of the supporting transfer arrangements. The revised transfer mechanism was based on a 1993 compromise under which every province was to be guaranteed a transfer sufficiently large to ensure a revenue no lower than that of 1993.

- Transfers ("fixed subsidies") under the old system were to be governed by the formula: ${ }^{11}$

Transfer $\geq\{1993$ base revenue -25 percent share of VAT-(most fixed local taxes and other)\}.

\footnotetext{
${ }^{10}$ See also Li Shi (2000).

${ }^{11}$ Bahl (1999) and Ma and Norregaard (1998).
} 
This commitment initially entailed a fixed transfer that would eventually become small in relative terms and the expectation was that this would be replaced by an equalization transfer.

However, a second transfer-known as "revenue returned" was also introduced that effectively preserved the 1993 relative inter-provincial distribution of resources.

- $\quad$ Revenue returned was to provide each province with 30 percent of the increase in VAT and excise taxes over the 1993 base. $^{12}$

The bases of each of these transfers were fixed in nominal terms, meaning that, with inflation, the revenue returned eventually swamped the transfers under the old system. Moreover, the revenue returned has been explicitly regressive, transferring more money to wealthier provinces. By 1998 , revenue returned was almost $2 / 3$ of total transfers, while the transfers under the old system were only about $3 \frac{1}{2}$ percent of the total (see Figure 3 ).

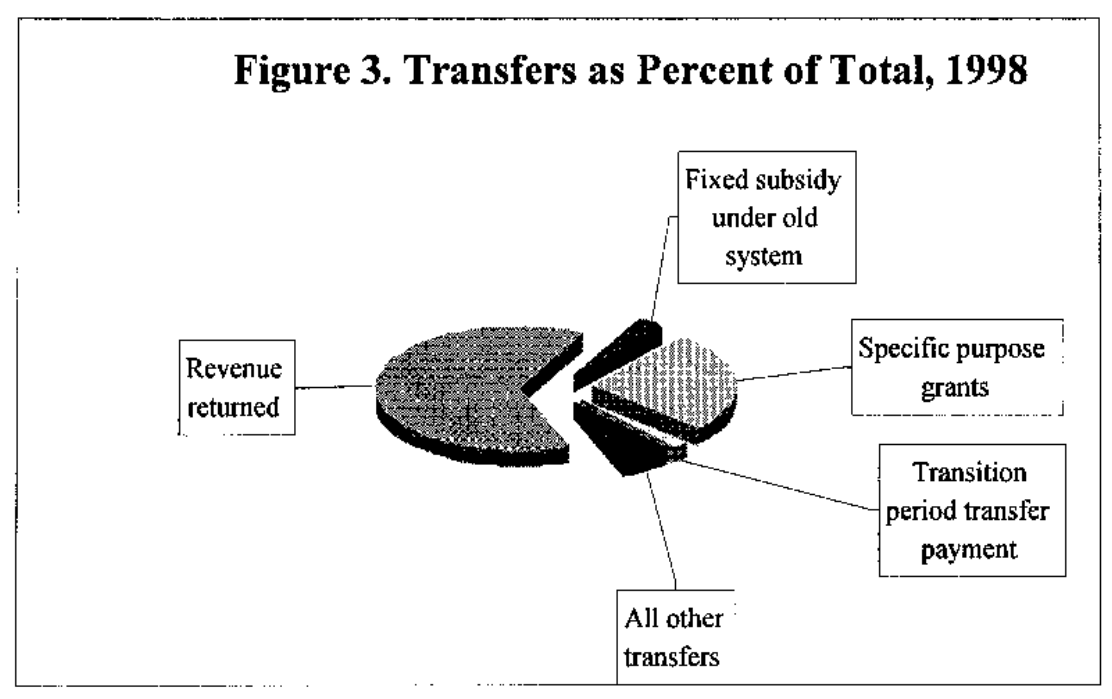

The other types of fiscal transfers in the post-1994 system include the following:

- Specific purpose grants are a large, and in recent years, growing share of the transfer pie. In 1998 they comprised more than a quarter of total transfers. There are hundreds of different earmarked grants, all of which are allocated on an ad hoc, negotiated

${ }^{12}$ Wong (2000). 
basis. Often they serve to provide SOE subsidies, as well as grants to enable local pension and unemployment systems to cover their shortfalls. 13

- Equalization transfers are meant to provide resources for equalization across China's provinces. They are rules based, and rely on variables like provincial GDP, student-teacher ratios, number of civil servants, and population density. However, these transfers have been sharply under-funded since their inception, rising in 1998 to only just under a meager level of 2 percent of total transfers.

Thus, in principle the available transfer mechanisms could provide a stable, rules-based framework for resource equalization across China's many provinces. In fact, however, owing to the reliance on the special purpose grants and the "revenue returned" window, the overall transfer system continues to be sharply regressive, rewarding wealthy regions with increased transfers (see Figures 4 and 5). The main element in the regressivity is the "revenue returned" (Figure 6), which is not offset by other transfers, including the relatively small equalization transfers (Figure 7).

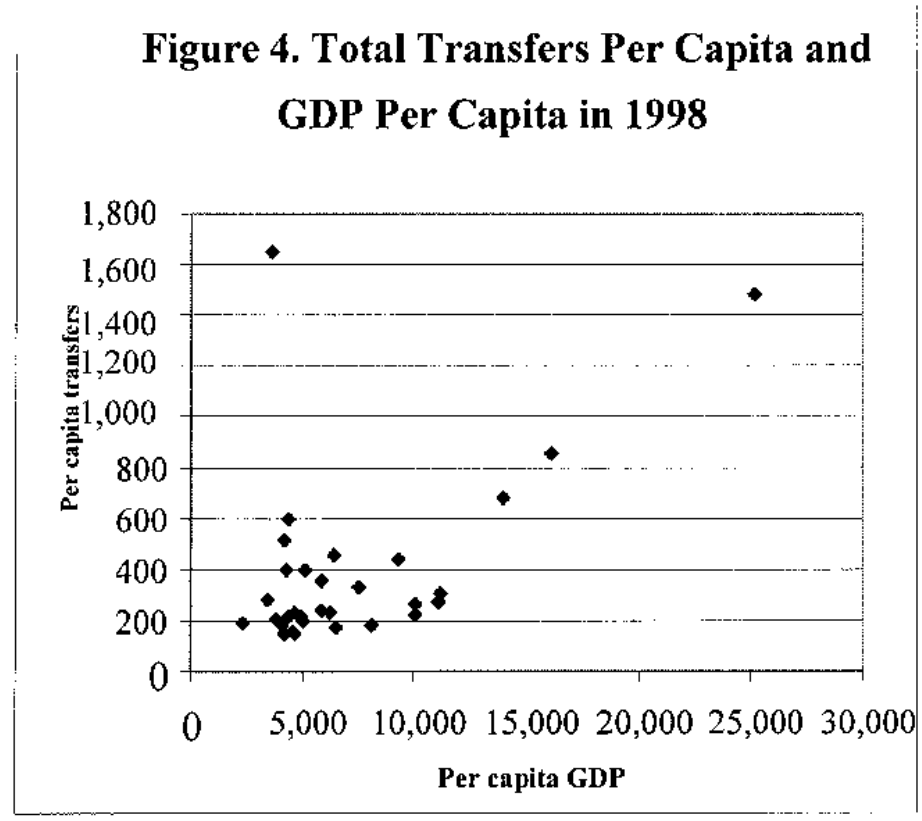

\section{Figure 5. Total Transfers and Own Revenue, as Percent of GDP, in 1998*}

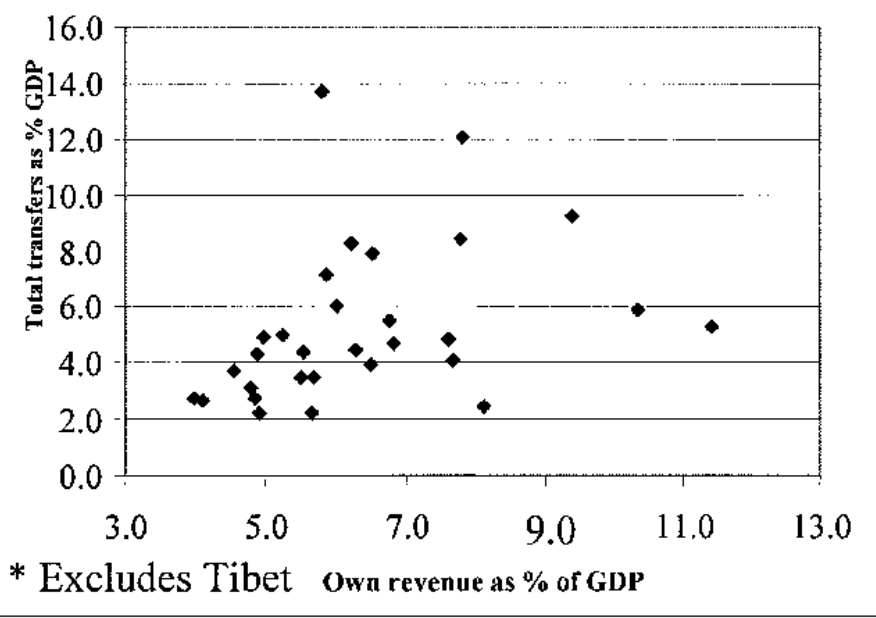

${ }^{13}$ These grants for the pension and unemployment systems in fact compensate for the financial inability of SOEs to meet their legal obligations under these programs, and hence are also akin to enterprise subsides. 


\section{Figure 6. Per Capita Revenue Returned and Per Capita GDP in 1998}

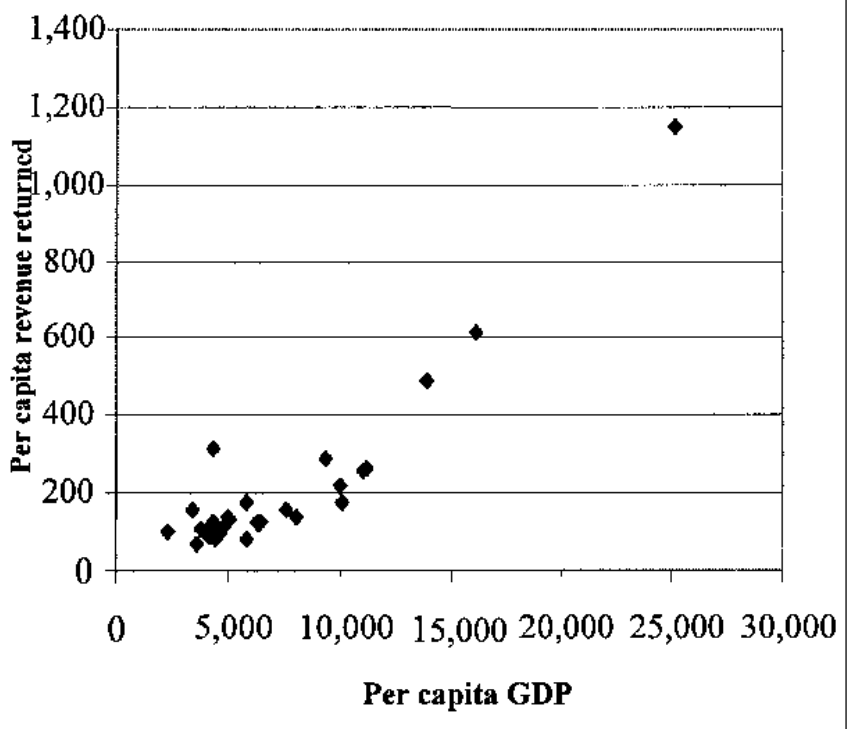

Figure 7. Per Capita Transfers Other than Revenue Returned and Per Capita GDP in 1998

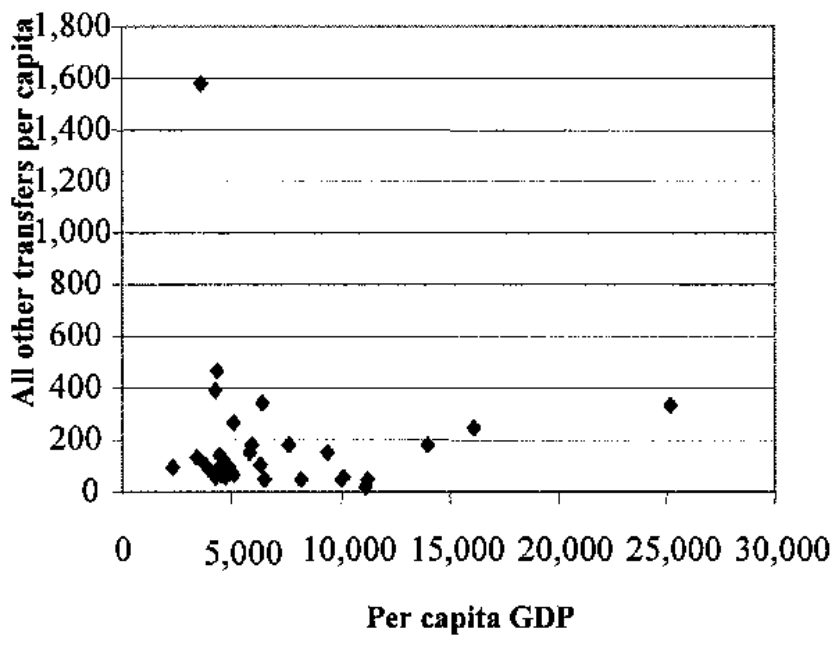

\section{Expenditure assignments}

In very general terms, the Chinese system of expenditure assignments, as set out in the constitution, is broadly consistent with international practice. The central government is responsible for national defense, external relations, capital construction of centrally owned enterprises, a number of central responsibilities in the areas of road and waterway construction, and servicing of public debt. Local governments are primarily responsible for local construction projects, most agriculture and water conservancy, education, health, culture, and most of the social safety net, including price subsidies. ${ }^{14}$ Nevertheless, in a number of areas-particularly social protection-there is effective overlap in responsibilities which serves to complicate both the revenue assignments and the needed design of the transfer system.

A critical difficulty relates to the responsibility for the social safety net. In a strict sense, the local governments are responsible, and China has relied on local (recently at the provincial level) pools even for pensions, unemployment insurance and the local (township level) provision of social assistance. When there is inadequate provision of social protection-e.g., delays in payments of pensions or unemployed workers without sources of support-the ultimate responsibility remains with the center, as do the downside risks of any social unrest.

\footnotetext{
${ }^{14} \mathrm{Ma}$ and Norregaard (1998).
} 
The situation in China is complicated by the restructuring of the state-owned enterprise (SOE) sector. Most SOEs provided social services ranging from kindergartens and health clinics to housing and hospitals. These services are in many cases being divested on efficiency grounds - this passes additional responsibilities on to local governments without the corresponding resources, effectively adding to their need for transfers or rationalization of the intergovernmental fiscal system.

These issues are discussed in further detail below.

\section{Macroeconomic Management with Multilevel Administration In China- The ReCEnt PaSt}

In theory, local governments are thought to be more efficient in the provision of public goods by virtue of their proximity to, and thereby better information about, end-users. Similarly, because residents could move, and thus match their preferences to the provision of local public goods, interjurisdictional competition is thought to improve welfare outcomes. ${ }^{15}$ Finally, some have emphasized the advantages of experimentation by subnational governments, a feature which has appealed to Chinese leaders, who have preferred to test reforms through extensive pilot projects.

Even in the Chinese context, the importance of informational asymmetries and incentives in institutional design cannot be ignored, such as the incentives facing bureaucrats at different levels of government (e.g., Qian and Roland, 1998). There may be an adverse incentive to assist in raising revenues that accrue to the center. Moreover, extensive reliance on transfers can affect local incentives to raise revenues from their own sources. ${ }^{16}$ Following the Asian crisis, much attention has been paid to the design of fiscal and monetary institutions, which minimize vulnerability and which are resistant to shocks. This has translated principally into a required design of revenue assignments and revenue-sharing systems that protect aggregate revenues. Similarly, on the expenditure side, there is a greater need for central instruments as a means of ensuring that fiscal policy can be appropriately tightened (or loosened) in a timely manner. ${ }^{17}$

Subnational governments in many parts of the world (particularly in Latin America) have sought to leverage their debt to gain concessions from the center. Indeed, Brazil came close to a financial crisis in $1998,{ }^{18}$ and there are continuing difficulties with the local incentives to

\footnotetext{
${ }^{15}$ See Oates (1972), Tiebout (1956), and Ter-Minassian (1997).

${ }^{16}$ Montinolo, Qian, and Weingast (1995).

${ }^{17}$ Eichengreen (1999), p. 57; Hemming and Petrie (2000).

${ }^{18}$ Tanzi (1995); Webb and Dillinger (1998), and World Bank (1999).
} 
borrow against overall general government debt constraints in a range of developing countries.

Conflicting incentives and macroeconomic constraints would suggest that, in China, the potential rewards of fiscal decentralization for better service delivery need to be balanced against its risks. ${ }^{19}$ On the one hand, lower level governments have better information about local needs, which should improve the efficiency of provision of local public goods. However, as noted by Ter-Minassian (1997) and others, income redistribution is less easily accomplished in a highly decentralized state, and short term macroeconomic management is generally thought to be more complicated when substantial revenue instruments or expenditure items are controlled by subnational governments. In this view, fiscal discipline is best achieved when revenue and spending responsibilities are broadly balanced at each level of government.

\section{A. Decentralization and Growth}

A number of researchers have argued that China's effectively decentralized fiscal system has had positive consequences for growth. Drawing on recent developments in the microeconomic theory of the firm, Qian and Weingast $(1996,1997)$ and Qian and Roland (1998) have argued that a form of "market-preserving federalism" has served to address incentive problems that otherwise might have undermined the commitment of central and local governments to market-style reform. In this view, the fact that local governments are equity holders in local SOEs has given them strong incentives to ensure that market conditions are conducive to the rapid growth of at least these firms, and to refrain from confiscatory taxation. At the same time, the political standing of local governments has been sufficiently strong to resist predatory taxation on the part of the central government. Moreover the center has had relatively limited information on local government finances. The result has been an environment that was extremely conducive to rapid capital accumulation and growth, particularly of small and medium sized firms controlled by provincial and local authorities. However, the absence of information on local finances provides ample opportunities for rent seeking. Thus, the opportunities that facilitated growth in the earlier period, now also constitute a political liability if there is misuse of resources or rent seeking behavior-particularly as the expectation of higher living standards is tempered through increasing inequalities.

In a cross section study, Davoodi and Zou (1998) have found that fiscal decentralization was not associated with more rapid economic growth in developing countries, while in developed countries the relationship was unclear. Decentralization is thought to be potentially harmful for growth because of the complications for macroeconomic management to which it gives rise (Tanzi (1996), but see Shah (1998) for a view to the contrary). In any case for China,

\footnotetext{
${ }^{19}$ See for example Feltenstein and Iwata (1999) and Ma (1997).
} 
Zhang and Zou (1998) have found a negative relationship between growth and decentralization.

\section{B. Decentralization and Fiscal Risk}

Macroeconomic management in China is complicated by the intergovernmental implications of a number of policy issues facing the authorities, including financial sector and enterprise reform, and the implications of those reforms for the provision of social services.

\section{Fiscal vulnerability}

Perhaps the most worrying feature of the revenue sharing system in China is the degree to which fiscal resources are collected and managed, not by the central government, but by other levels of government. The most immediate fiscal vulnerability is thus the difficulty the central government could have in meeting its debt servicing obligations. Interest on government debt, which by law can only be issued by the central government, rose from 10.5 percent of central government own revenue in 1996 to 13.3 percent in 1997 and 15.1 percent in 1998. In 1999, owing to rapidly rising customs revenues and domestic debt for which the interest burden was postponed by means of balloon payments at maturity, this ratio fell back to 10.5 percent, but to stay at this level central government revenues will need to continue to rise.

The debt burden of the central government is slated to grow dramatically over the period ahead, moreover. Bonds placed for fiscal stimulus purposes in the aftermath of the Asian crisis will need to be serviced, as will at least a portion of AMC bonds. Ultimately, of course, the cost of restructuring the financial sector will fall on the central government. As a result, there is a need for a greater share of fiscal resources at the central level, effectively for precautionary reasons.

China's intergovernmental system has also given rise to dysfunctional behavior, such as indirect borrowing. Local governments, though forbidden to borrow openly, have attempted to do so through window corporations and banks, with the result that the central government is not in a position to monitor, much less manage, gross public debt.

\section{State-owned enterprise (SOE) reform}

The Chinese authorities have long signaled their intention to restructure the SOE sector, and this effort has taken on new importance with its entry into the World Trade Organization (WTO), since foreign competition will put the public enterprise sector under increased pressure. Although operating losses of the state enterprises have traditionally been covered by loans from the state banking system, the authorities' intention to streamline and modernize the financial sector are closing off this financing source. Hence, SOEs are being forced to adapt to market conditions, and this process is generating a variety of pressures that impinge upon the multi-level fiscal system. 
Industrial location policy under central planning directed resources to inland provinces, particularly for the establishment of heavy industry, which now faces significant restructuring. Thus, regions with outdated industrial technology are likely to face high social costs given the unemployment consequences of restructuring. Yet pooling of unemployment contributions within provinces has been very limited and virtually negligible across provinces. Since the unemployment system is largely funded by a uniform payroll tax, several local governments are flush with unemployment insurance funds that are not used effectively, whereas other localities do not have enough from the unemployment wage tax to cover minimum benefits, or adequate funds from other revenues to be able to meet the costs for the unemployed. This acts as a constraint on the scope for SOE restructuring.

Note that the existing horizontal imbalances also complicate attempts to use a macroeconomic stimulus to bolster the social safety net. In 1998 and 1999, the central government undertook significant fiscal expansions, and most of the spending took the form of capital investments. Some observers argued that social safety net spending might prove more effective in stimulating aggregate demand, and in facilitating SOE reform. However, the central authorities were reportedly wary of doing too much in this regard for fear of generating moral hazard problems with local governments (that might well have diverted their own spending on the social safety net to other uses, negating the social impact of the expansion).

\section{Financial sector restructuring}

Persistent losses in the SOE sector have been financed through continued lending by the state owned banks, and these losses will eventually need to be covered through fiscal transfers from the central budget. While the geographic distribution of "bad loans" is not well known, it is likely to be coincident with China's rust belt of presumably loss-making SOEs. Thus, any recapitalization of state banks may have an implicit element of intergovernmental transfer. Indeed, already there have been reports that bailing out state banks have proven difficult due to political disagreements over burden sharing (who should pay) and the allocation of benefits. ${ }^{20}$

\section{Social security reform}

China has a pension system based on pooling at the provincial level. Central pooling has been opposed on the grounds that this may involve transfers from poorer provinces with relatively young demographic profiles to those with a greater proportion of pensioners (especially along the coast)—but which also have much higher standards of living. However, because of limited pooling, a horizontal imbalance arises in regions with high concentrations

\footnotetext{
${ }^{20}$ A similar problem arises with respect to local government borrowing through locally owned and managed financial institutions, where bankruptcy may be politically difficult. GITIC, for example, was controlled by the provincial government of Guangdong.
} 
of SOEs and a high dependency ratio of pensioners to pension fund contributors (e.g., in the coastal regions). As a result, to finance pension liabilities on a pay-as-you-go (PAYG) basis, payroll tax rates have risen to unsustainable levels in many localities, and pension arrears are becoming common.

In 1998 and 1999 the central authorities resorted to ad hoc fiscal transfers in order to settle outstanding pension obligations, and undertook a significant centralization in the form of mandatory provincial pooling for all industrial enterprises, regardless of ownership or industry. With the ratio of pensioners to working population in China rapidly approaching that in Europe and Japan, even with national pooling the PAYG system as a whole will need restructuring and possible central transfers in the near future. An additional concern arises concerning the management and oversight of the existing pension funds at the local level

Similarly, with unemployment insurance, local pools do not provide sufficient pooling of risks - the localities that need the funds most (because of SOE restructuring) do not have sufficient resources to provide for the unemployed, whereas others have idle balances in funds that may not be effectively managed.

A wide-ranging reform of the social security system in China may involve a centralization of the pooling and financing mechanisms, perhaps with a centralized payroll tax or charge-this however need not imply reduced functions for local governments. Indeed by treating all the aged, and the unemployed, equally across China, the center would be able to relieve burdens on local governments (particularly along the coastal regions) that could facilitate a greater degree of progressivity in the tax-transfer system as a whole.

\section{Information flows and public expenditure management issues}

China remains a unitary state in which the ultimate responsibility for expenditures remains with the center. However, at this stage, the center lacks the instruments to track expenditures, including those made by sub-national bodies on behalf of and with direct financing from the center. Even some payments made by the center for central government operations, such as some central wage liabilities, and financing for the construction of grain silos (a central government responsibility) are often routed through local government. A central difficulty is that center lacks the means to ensure that such payments are made in a timely fashion.

The difficulty is exacerbated when certain local expenditures are required by the center, with requisite financing provided through special purpose programs. Such programs may include basic education to a certain level. The center lacks the mechanisms to monitor compliance with the objectives of special purpose programs, which may be diverted to other priorities of the local governments. Attempts by the Ministry of Finance at the present time to create an effective treasury system should assist in the transparency of central and sub-national expenditures. However, these reforms are likely to become effective only in the mediumterm, i.e., within a four or five year time horizon. The recent revenue gains should continue to be consolidated. 


\section{IMPLICATIONS OF CHANGING INTERgOVERNMENTAL DYNAMICS}

\section{A. Revenue Assignments-Vertical and Horizontal Imbalances?}

A number of issues arise out of the foregoing discussion. In part, the fiscal management system needs to be modernized in a way that allows accurate information to flow to policy makers at all levels. But it is also likely that the fiscal federal system itself will need to be revised to take into account the pressures to further reform the tax system.

The principal tax policy changes are dictated in part by China's prospective entry into the World Trade Organization, and also to rationalize the process initiated in 1994. The key policy measures include:

- The reform of the VAT - including from production to consumption basis will lead to changes in revenues generated in specific regions, thus affecting the returned revenue. Moreover, the extension in coverage of the VAT, supplanting business taxes, which accrued to local authorities, will open up the question of appropriate county and city-level tax bases, and the design of transfers.

- $\quad$ Elimination of nuisance fees and charges levied by the county-level administrations, and their potential replacement by excises, e.g., fuel taxes, has been opposed because of the potential centralization of a local tax base. In late 1999 the National Peoples Congress finally removed the last legal roadblock to introduction of a central fuel tax that is meant to replace a half dozen local fees assessed on essentially the same tax base, the authorities have been unable to implement the change as a result of local government opposition. However, there is scope to view such excises as a shared tax base, with more than one level of government levying such taxes (within bounds) - and there is clearly scope to "persuade" local governments.

- The assignment of the personal income tax to local governments may need to be reconsidered, given its potential revenue generation capability as the economy expands. Typically, in industrial countries, the largest share of the personal income taxes accrues to the central government, although lower levels in some countries also share the base and are permitted to levy a up to a certain number of percentage points. Given the Chinese central government's revenue needs (e.g., for enterprise and bank restructuring, or for redistribution), it may be advisable to introduce such reforms before the revenue generated from this head becomes too large-else there will be a reluctance on part of the local governments to cede this base to the center.

- For assigned local taxes, a degree of control over rate structure is critical in ensuring local accountability. Otherwise the local government does not have at its disposal means of financing additional local expenditures by inflicting the burden on local citizens. As seen in recent years, there is then a tendency to obtain additional revenues by circuitous means. 
It may be useful to revise revenue assignments and sharing rules at this stage with an eye toward giving subnational governments bounded tax setting authority. In the absence of greater local revenue autonomy, it will continue to be difficult to convince local authorities to do away with the many fees and charges, which now serve to finance off-budget local expenditures. However, changes in these assignments will necessitate a review of resulting horizontal and vertical imbalances and need for transfers.

\section{B. Specification of Expenditure Assignments}

Unlike in the past, there is a need to specify expenditure assignments and responsibilities to ensure effective service delivery at the city and county level. This is important as SOEs shed responsibilities for enhanced efficiency.

The role of the social safety net also needs to be examined-including central pooling pursuant to the creation of a social security tax, should the authorities decide to move in that direction. While a centrally financed pension and unemployment insurance system may appear to be a "recentralization" move, in effect it would remove a major constraint on local governments enabling these to more effectively provide public services such as basic health and education.

There is a need to reassess the system of expenditure assignments in China's fiscal system. On paper, the system seems to match international practice, with national public goods like defense handled centrally, and others that vary with local characteristics, such as education, managed locally. However, in practice some activities are managed by several levels of government simultaneously, giving rise to inefficient delivery of services. ${ }^{21}$ Beyond the budget, a great deal of progress remains to be made in deciding which activities should be done by the state at all, and which should be handed over to the private sector.

Moreover, there are some activities, which, by virtue of their magnitude, cannot be handled by local governments alone. For example, some environmental projects demand resources from the central government, and a number of transition-related expenditures in rust belt regions-because the rust belts were initially created at central government behest-will need to be co-financed by the center.

Finally, the question of local government borrowing for legitimate capital purposes remains contentious in China, as elsewhere in the developing world. On the one hand, the outright prohibition of local borrowing can be inefficient-in that projects with high social rates of return might not be funded. A total prohibition can also be evaded, such as when local governments borrow through window corporations. In China both factors are evident. On the other hand, once local governments have a borrowing window to which they can turn, serious incentive problems are unavoidable in that local governments - and creditors-have reason

${ }^{21}$ Wong (2000). 
to borrow excessively in the expectation of a central government bailout in case of difficulty. To date, the authorities have forbidden explicit local government borrowing, but local public enterprises regularly undertake debt issuance for projects, which appear to be public in nature.

In the absence of an efficient capital market and monitoring and reporting mechanisms, it may be premature to move quickly to a system that permits explicit borrowing by local governments, subject to borrowing limits. The individual limits for all local governments may be inconsistent with the overall limit for general government debt consistent with a sustainable macroeconomic stance. Thus, in the short term, it may be prudent to permit some local borrowing subject to approval by the center.

\section{Design of Transfers}

In order to achieve greater horizontal equity across provinces, it will be important to reorient fiscal transfers away from "revenue returned" towards a system of rules based equalization grants. This idea has been suggested for some time, but the size of the "equalization" transfer scheme remains tiny.

During 2000, the authorities have sought to address some of the regional inequalities through an explicit policy of developing the western and central provinces. To some extent, this program would be less urgent had an adequately funded system of equalization grants been in place. Indeed, as shown in Figure 8, fiscal revenue per capita wealthy coastal provinces like Zhejiang and Fujian, after taking account of all transfers and extrabudgetary revenues, is as much as twice that of poorer inland regions like Gansu and, to a lesser extent, Yunnan. ${ }^{22}$

Figure 8. Composition of Revenue in Four Provinces, 1998

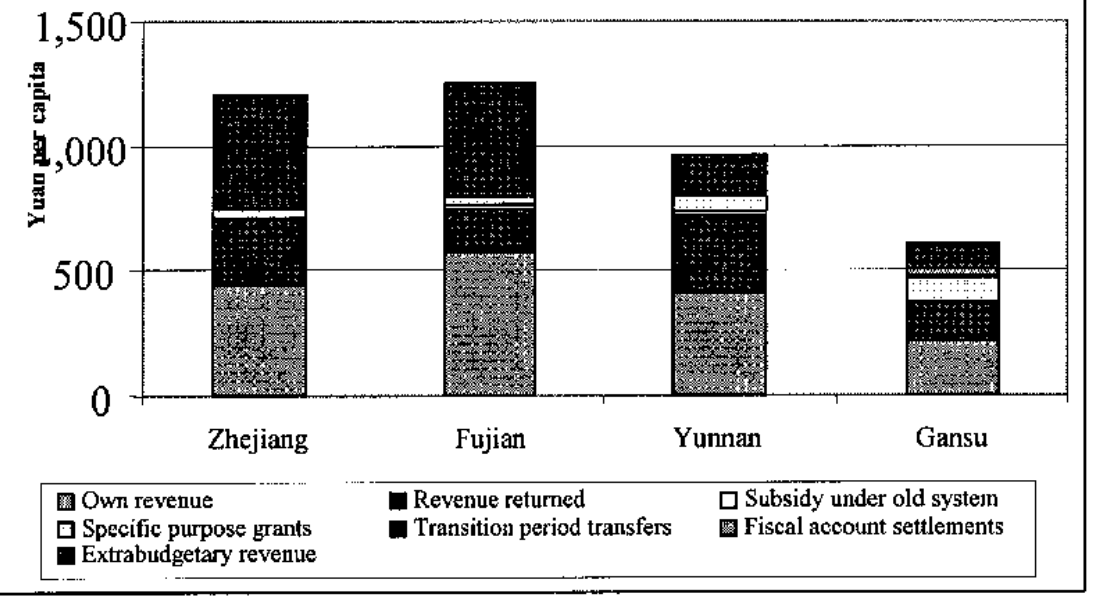

${ }^{22}$ Yunnan province has relatively high per capita fiscal revenue because of the importance of tobacco (which affects "revenue returned" through the excise tax) in provincial public finance. 
In the absence of a sufficiently large effective vertical imbalance that permits the functioning of a significant equalization mechanism, the center has been tempted to resort to a better targeting of special purpose grants. The main difficulty with this reliance on special purpose grants are that the center lacks the monitoring mechanisms to ensure effective use. Also, the ad hoc decisions of the center may not fully take into account the overall directions that might lead to horizontal equity.

However, as described in Lou Jiwei (1997), ${ }^{23}$ if there is an overall framework, it would make eminent sense to rely initially on a better targeting of special purpose grants while the full equalization system is being developed. While there is an increasing capability in China to design and implement an equalization grants system, the constraints remain essentially political and may need a coherent review of the revenue assignments together with the establishment of expenditure responsibilities and a consistent transfer design to act in support of an overall reform.

\section{Conclusions}

It was hoped that the 1994 fiscal system reform would contribute to an increase in the "two ratios": revenue to GDP and the central share in state budget revenue. Following some modest initial success with the latter, neither ratio rose appreciably during most of the period following the reform. Fiscal revenues remained low until central efforts to control tax evasion and introduce treasury discipline were made in the late 1990s. While the revenue decline of the mid-1990s was owing to a number of factors, including those common to many transition countries, adverse incentives in the fiscal federal system also appear to have played an important role. Transfers have been inadequate and are not based on expenditure necessities. Provinces have extremely limited revenue-raising authority, which means they have strong incentives to keep resource flows outside the budget (indeed, often in the locally owned public enterprise sector). Moreover, despite considerable evolution in the role of the state in the Chinese economy, expenditure assignments have not been fundamentally reassessed since 1994.

We have argued that a comprehensive reform of the intergovernmental fiscal system is needed in China. This effort should emphasize clear delineation of revenue bases and local authorities will need to be given greater freedom to set tax policy in accordance with local conditions. There has to be greater precision concerning the expenditure responsibilities, and there should also be an attempt to clarify the role of local contingent liabilities, which may have arisen outside the budget. The restructuring of the social security system, particularly for pensions and unemployment insurance, will also have an impact on the local need for financing. The transfer system will need to be revised to reflect local revenue capacity and expenditure needs in a rules-based manner. Ultimately, reducing vulnerabilities in this area

${ }^{23}$ See also Mihaljek in Alumad (1997). 
will necessitate making significant progress in fiscal management reforms of treasury and budget-management processes. 


\section{REFERENCES}

Ahmad, Ehtisham, 1997a, "China," in Fiscal Federalism in Theory and Practice, ed. by Teresa Ter-Minassian (Washington: International Monetary Fund). , ed., 1997b, Financing Decentralized Expenditures (Northampton, Massachusetts: Edward Elgar).

, Gao Qiang, and Vito Tanzi, eds., 1995, Reforming China's Public Finances (Washington: International Monetary Fund).

Arora, Vivek, and John Norregaard, 1997, "Intergovernmental Fiscal Relations: The Chinese System in Perspective" IMF Working Paper 97/129 (Washington: International Monetary Fund).

Bahl, Roy, 1999, Fiscal Policy in China: Taxation and Intergovernmental Fiscal Relations, (San Francisco: 1990 Institute).

Blanchard, Olivier, and Andrei Shleifer, 2000, "Federalism With and Without Political Centralization: China versus Russia," NBER Working Paper No. 7616 (Cambridge, Massachusetts: National Bureau of Economic Research).

Davoodi, Hamid, and Heng-fu Zou, 1998, "Fiscal Decentralization and Economic Growth: A Cross-Country Study," Journal of Urban Economics, Vol. 43 (March), pp. 244-57.

Eichengreen, Barry, 1999, Toward a New International Financial Architecture: A Practical Post-Asia Agenda (Washington: Institute of International Economics).

Feltenstein, Andrew, and Shegeru Iwata, 1999, "Decentralization and Economic Stability in China: Regional Autonomy has its Costs," draft paper (July).

Hemming, Richard, and Murray Petrie, 2000, "A Framework for Assessing Fiscal Vulnerability," IMF Working Paper 00/52 (Washington: International Monetary Fund).

Jin, Hehui, Yingyi Qian, and Barry R. Weingast, 1999, "Regional Decentralization and Fiscal Incentives: Federalism, Chinese Style," draft paper (March).

Laffont, Jean-Jacques, 1999, “Incentives in China's Federal Tax System” unpublished, manuscript.

Lardy, Nicholas, 1998, China's Unfinished Economic Revolution (Washington: Brookings Institution). 
, 1999, “When Will China's Financial System Meet China's Needs?" paper presented at the Conference on Policy Reform in China, Stanford University, November 18-20.

Li, Shi, 2000, "Efficiency and Redistribution in China's Revenue Sharing System," in Governance, Decentralization and Reform in China, India and Russia, ed. by Jean-Jacques Dethier (Dordrecht: Kluwer Academic Publishers).

Lou, Jiwei, 1997, "Constraints in reforming the transfer system in China," in Financing Decentralized Expenditures, ed. by Ehtisham Ahmad (Northampton, Massachusetts: Edward Elgar).

Ma, Jun, 1997, Intergovernmental Relations and Economic Management in China, (New York: St. Martins). , and John Norregaard, 1998, "China's Fiscal Decentralization," IMF, unpublished manuscript (October).

Montinolo, Gabriella, Yingyi Qian and Barry R. Weingast, 1995, "Federalism, Chinese Style: The Political Basis for Economic Success in China," World Politics, Vol. 48 N1, pp. 50-81.

Oates, Wallace, 1972, Fiscal Federalism (New York: Harcourt, Brace Jovanovich).

Qian, Yingyi, 1999, “The Institutional Foundations of China's Market Transition,” paper prepared for World Bank ABCDE Conference (April).

, and Gerard Roland, 1998, "Federalism and the Soft Budget Constraint," American Economic Review, 88, 5 (December) pp. 1143-62.

, and Barry R. Weingast, 1997, "Federalism as a Commitment to Market Incentives," Journal of Economic Perspectives, 11, 4, pp. 83-92.

, and Barry R. Weingast, 1996, "China's Transition to Markets: Market-Preserving Federalism, Chinese Style," Journal of Policy Reform, 1, pp. 149-185.

Shah, Anwar, 1998, "Fiscal Federalism and Macroeconomic Governance: For Better or For Worse?" World Bank Policy Research Working Paper 2005 (November).

Tanzi, Vito, 1995, "Fiscal Federalism and Decentralization: A Review of Some Efficiency and Macroeconomic Aspects," in Annual World Bank Conference on Development Economics, ed. by Michael Bruno and Boris Pleskovic (Washington: World Bank).

Ter-Minassian, Teresa, 1997 “Decentralization and Macroeconomic Management,” IMF Working Paper 97/155 (Washington: International Monetary Fund). 
, ed., 1997a, Fiscal Federalism in Theory and Practice (Washington: International Monetary Fund).

, and Jon Craig, 1997, "Control of Sub-national Government Borrowing," in Fiscal Federalism in Theory and Practice, ed. by Teresa Ter-Minassian (Washington: International Monetary Fund).

Tiebout, Charles, 1956, “A Pure Theory of Local Expenditures,” Journal of Political Economy, 64 (October), pp. 416-24.

Webb, Steven and William Dillinger,1998," Fiscal Management in Federalized Democracies: Argentina and Brazil," draft paper.

Wong, Christine P., 2000. "Central-Local Relations Revisited: the 1994 Tax Sharing Reform and Public Expenditure Management in China," World Bank Office in China (April). , ed., 1997, Financing Local Government in the People's Republic of China, published for the Asian Development Bank by Oxford UP.

, Christopher Heady and Wing T. Woo, 1995, Fiscal Management and Economic Reform in the People's Republic of China, published for the Asian Development Bank by Oxford UP. , 1991, "Central-Local Relations in an Era of Fiscal Decline: The Paradox of Fiscal Decentralization in Post-Mao China," China Quarterly (December) pp. 691-715.

World Bank, 1999, Beyond the Center: Decentralizing the State, (Washington, DC).

Zhang, Tao, and Heng-fu Zou, 1998, "Fiscal Decentralization, Public Spending and Economic Growth in China," Journal of Public Economics, Vol. 67, pp. 221-40. 